\title{
AN EXPERIMENTAL RESEARCH ON HYSTERETIC BEHAVIOR OF RC BEAMS UNDER SIGNIFICANT GRAVITY LOADS
}

\author{
Dr. Öğr. Üyesi Cem AYDEMİR \\ İstanbul Aydın University, \\ Department of Civil Engineering \\ cemaydemir@aydin.edu.tr
Doç. Dr. Müberra ESER AYDEMIR İstanbul Aydın University Department of Civil Engineering muberraaydemir@aydin.edu.tr

\section{P1nar YILDIRIM} \\ İstanbul Aydın University \\ pinaryildirim@aydin.edu.tr \\ https://orcid.org/0000-0002-6667-9365
}

\begin{abstract}
In this study, hysteretic behavior of RC beams with and without significant gravity load effects are investigated. To this purpose, an experimental program is carried out in which gravity loads are applied by force controlled test procedure whereas cyclic loads are applied by displacement controlled test procedure. The results of tests with gravity load effect are compared with the results of control specimens with increasing displacement loading profile. Experimentally observed damage states and deformation demands are compared with the respective values proposed by Turkish Seismic Design Code. It is found that, the loading procedure with significant gravity load effect leads to the formation of unidirectional plastic hinges. Besides, the deformation capacities of the specimens are found to be much higher than the code based deformation capacities.
\end{abstract}

Keywords: Damage Limits, Rotation Capacity, Strain Limits, Experimental Load Displacement Relations, Plastic Hinge Length 


\section{BELİRGIN DÜŞEY YÜKLER ALTINDAKİ BETONARME KİRIŞLERIN ÇEVRIMSEL YÜKLER ETKISINNDEKI DAVRANIŞLARI ÜZERINE DENEYSEL BİR ÇALIŞMA}

\section{ÖZ}

$\mathrm{Bu}$ çalışmada, düşey yük etkilerine maruz bırakılan ve bırakılmayan betonarme kirişlerin çevrimsel davranışları incelenmiştir. Bu amaçla, düşeyi yükler kuvvet kontrollü, çevrimsel yüklerin deplasman kontrollü uygulandığı deneysel bir program yürütülmüsştür. Düsşey yük etkisinin dikkate alındığı deneysel sonuçlar sonuçları, düşey yük etkisinin dikkate alınmadığı yükleme profiline sahip deney numunelerinin sonuçları ile karşılaştırılmıştır. Deneysel olarak gözlemlenen hasar durumları ve deformasyonlar, Türk Deprem Yönetmeliği tarafından önerilen değerlerle karşılaştırılmıştır. Belirgin düşey yük etkisi ile yükleme profilinin tek yönlü plastik mafsalların oluşumuna neden olduğu gözlemlenmiştir. Ayrıca, numunelerin deformasyon kapasitelerinin, yönetmelikte verilen deformasyon kapasitelerinden çok daha yüksek olduğu belirlenmiştir.

Anahtar Kelimeler: Kesit Hasar Sinırları, Dönme Kapasitesi, Birim Şekil Değiştirme Sinırları, Deneysel Yük-yer Değişstirme İlişkileri, Plastik Mafsal Boyu

\section{INTRODUCTION}

Current earthquake design codes $[1,2]$ allow the inelastic and nonlinear behavior of structures when the ductile behavior and plastic hinge mechanism that ensures energy absorption is sustained. Potential damage points are intended to occur at the ends of beams due to flexure with some design principles such as strong column-weak beam principle, ensuring of shear resistance at column-beam joint and capacity design procedure. To this purpose, plastic rotation capacities of beam ends have a great importance for structural performance assessment. Quasistatic tests are widely preferred in experimental researches on plastic rotation capacities of beam under cyclic loads due to its simplicity. Load and deformation capacity of a specimen is obtained based on the imposition of cyclic displacement histories defined with ECCS [3], ACI [4] or ATC [5] recommendations.

Unidirectional flexure occurs at beam ends under gravity loads whereas reversing flexure occurs under both vertical and earthquake loads. Reversing plastic hinges form when the reversing flexure moment demand is greater than the positive and negative yielding capacities of section. If the cycling flexure moment demand is greater than the yield capacity of section in one direction, unidirectional (for negative moment direction) plastic hinge occurs. In other words, significant gravity loads can affect the plastic hinge mechanism to be unidirectional or reversing. 
Previous researches mainly use loading histories cause inelastic behavior under both positive and negative moment to investigate the cyclic behavior of RC beams. [6-13]. These studies usually ignore the effects of gravity load since there is a limited number of researches focusing on significant vertical load effect. Walker and Dhakal [14] conducted an experimental study and they reported that curvature ductility at unidirectional plastic hinge under significant gravity load can be taken two times of the one at reversing plastic hinge. Gião et.al. [15] developed a quasi-static test procedure for $\mathrm{RC}$ beams under significant vertical load and compared the analytical and experimental results.

In this study, variation of plastic rotation capacities of reinforced concrete beams with transverse reinforcement ratio less than the minimum ratio due to vertical loads are investigated.

\section{EXPERIMENTAL PROGRAM}

The experiments are conducted at the Structural Testing Laboratory. Two identical cantilever beam specimens with dimensions of $25 / 50 \mathrm{~cm}$ are produced. Yield strengths of reinforcing bars are $498 \mathrm{MPa}$ for both samples whereas compression strengths of concrete is $48.6 \mathrm{MPa}$ for sample K6.0LP1 and 44.5 MPa for sample K6.0LP2. Geometric properties and test setup of samples with shear span / effective depth ratio equal to 6.0 are illustrated in Fig.1 and 2, respectively.
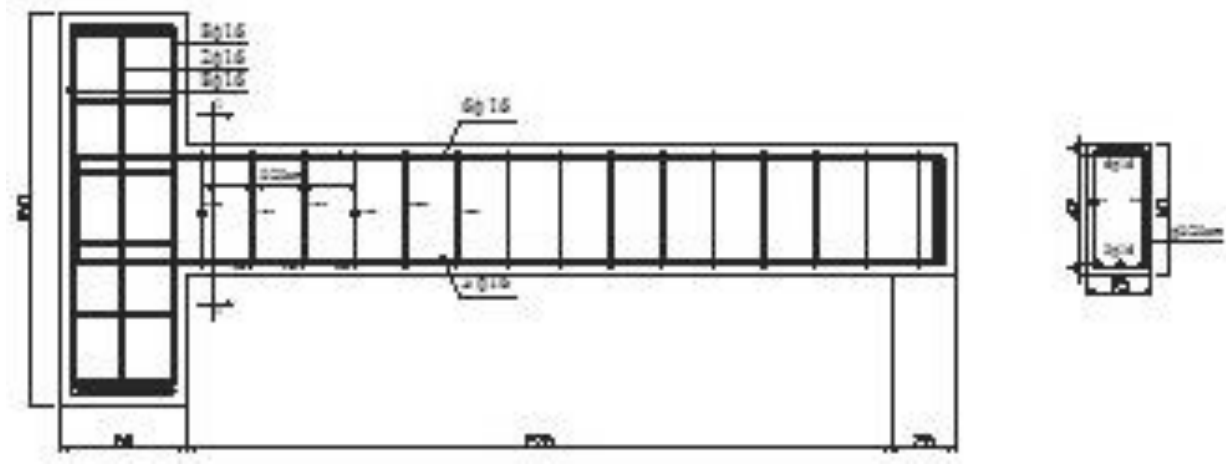

Şekil 1: Geometry, detailing and instrumentation of the specimens K6.0LP1 and K6.0LP2 


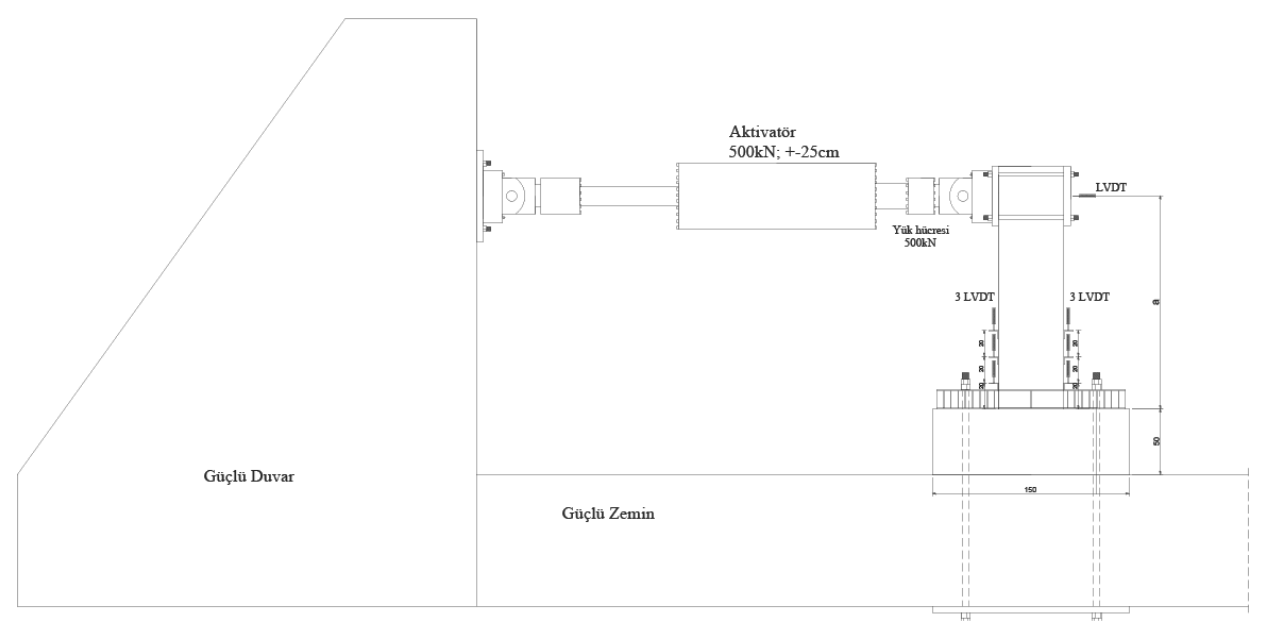

Şekil 2: Test setup

In test procedure, two different load profile is used. First loading profile (LP1) is displacement controlled and applied to K6.0LP1, whereas the second loading profile (LP2) is both load and displacement controlled and applied to K6.0LP2. These profiles can be seen in Figs. 3 and 4, respectively. As it is seen from Fig. 5 , first step of LP2 is application of gravity load as a force controlled step. In this study, the gravity load is considered as the $50 \%$ of the horizontal force that leads the top reinforcement to yielding. [15].

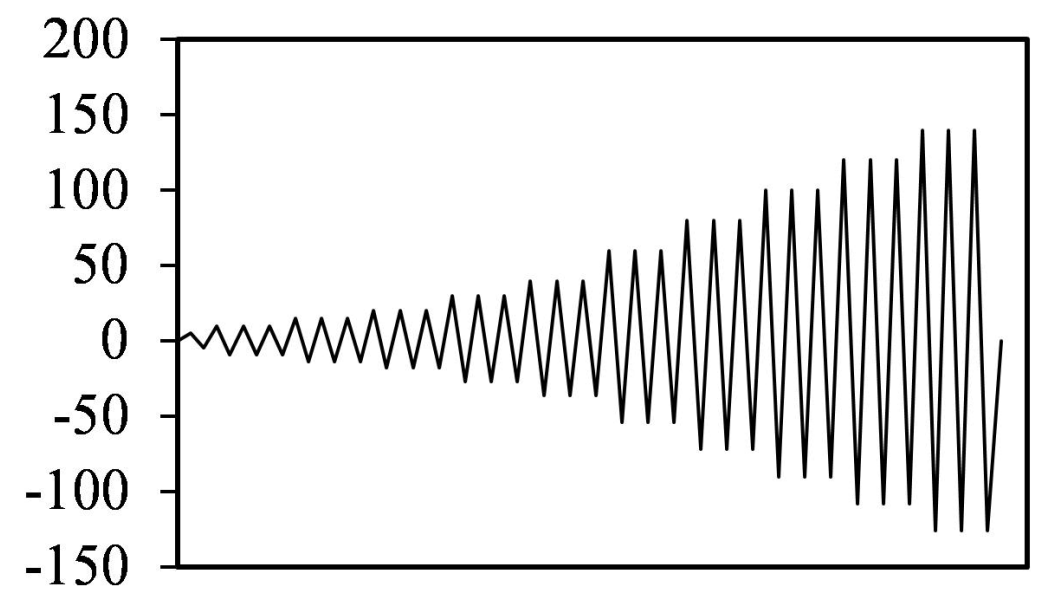

Şekil 3: YP1: Displacement history of specimen K6.0LP1 


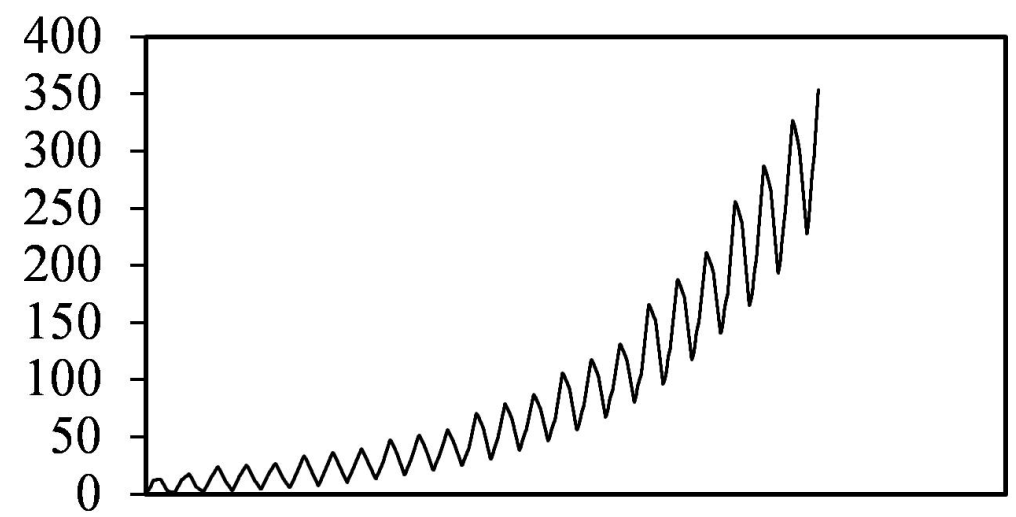

Şekil 4: YP2: Displacement history of specimen K6.0LP2

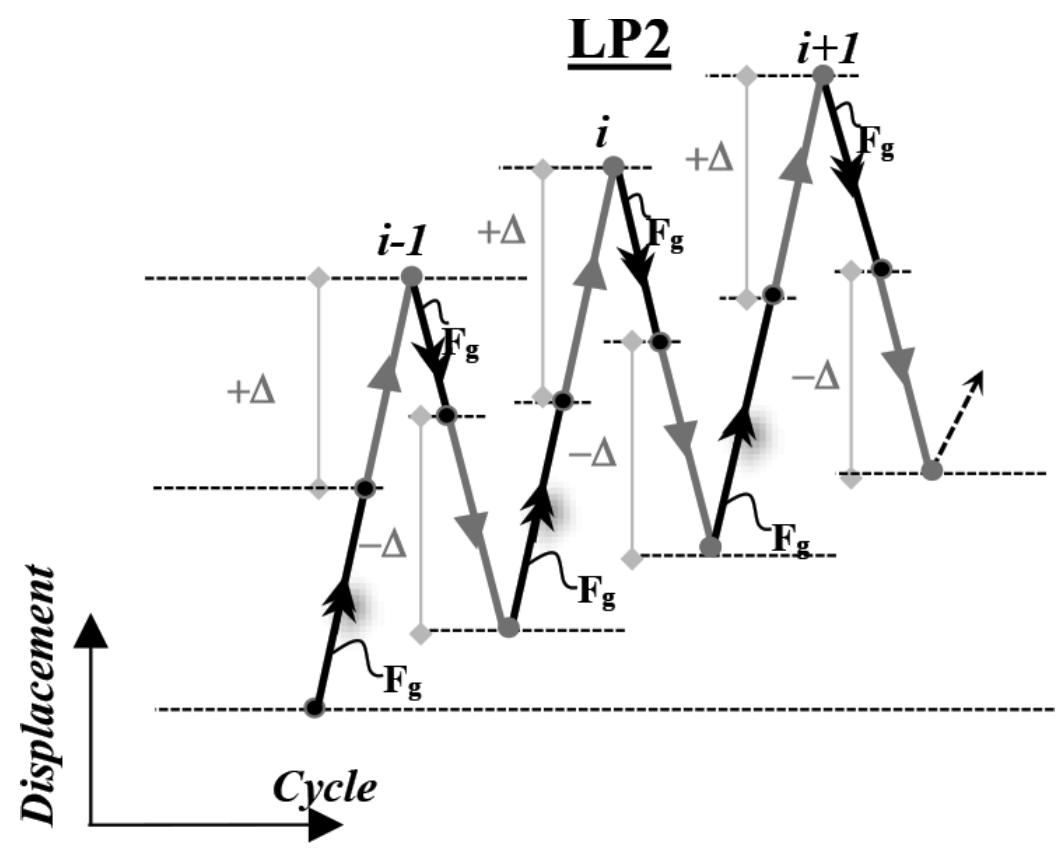

Şekil 5: Typical load cycle in the LP2 test procedure of specimen K6.0LP2 [15] 


\section{EXPERIMENTAL RESULTS}

Load-displacement response of test specimens are shown in Figs 6 and 7. Various damage limit states observed during the experiments are illustrated in the figures. The most notable observations, in sequence of first occurrence, are concrete cracking, longitudinal reinforcement yielding, initial spalling of the concrete cover, complete spalling of the concrete cover, longitudinal reinforcement buckling, and longitudinal reinforcement fracture. Also the final failure modes of specimens are presented in Figs. 8 and 9.

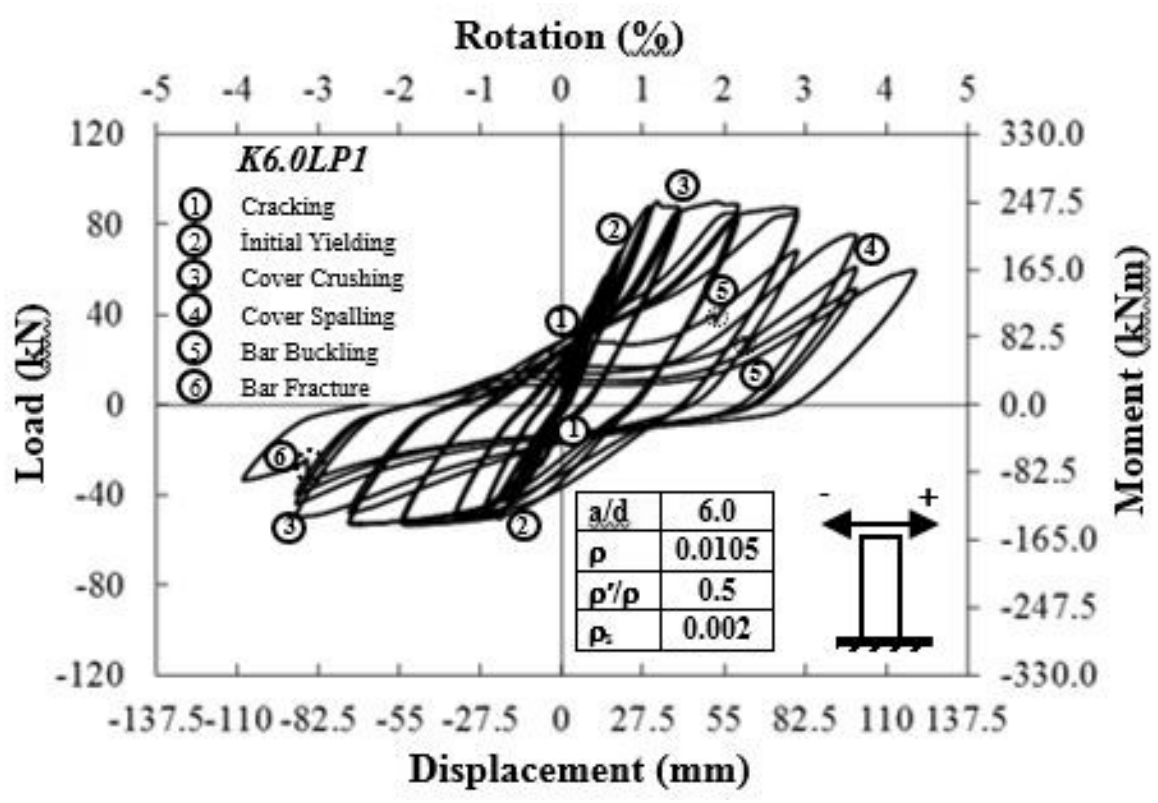

Şekil 6: Force-displacement hysteretic diagram of specimen K6.0LP1

For K6.0LP1 specimen which is subjected to displacement controlled LP1 profile, reversing plastic hinges occurred for both positive and negative flexure directions. Significant decrease in moment bearing capacity corresponds to buckling of compression reinforcement and confined concrete core crushing in negative bending and rupture of tensile reinforcement in positive bending of bottom reinforcement. As the longitudinal reinforcement configuration is nonsymmetrical, load-displacement response of specimen is non-symmetrical and damages occur in bottom reinforcement. 


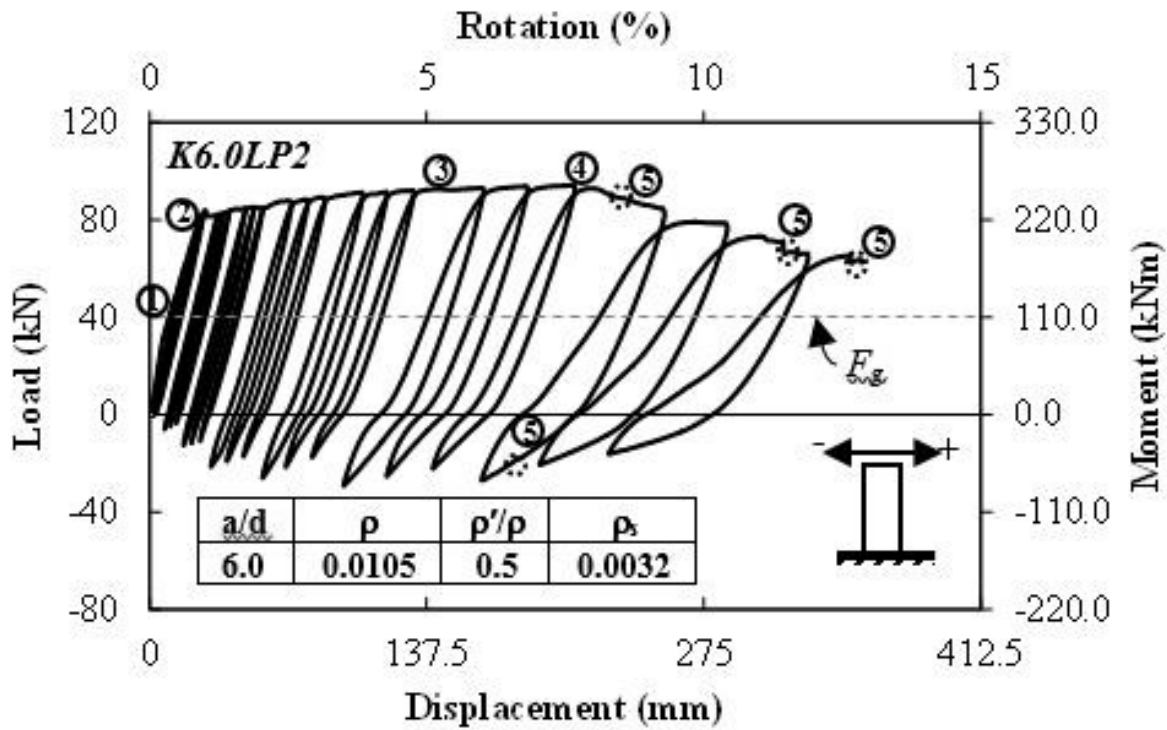

Şekil 7: Force-displacement hysteretic diagram of specimen K6.0YP2
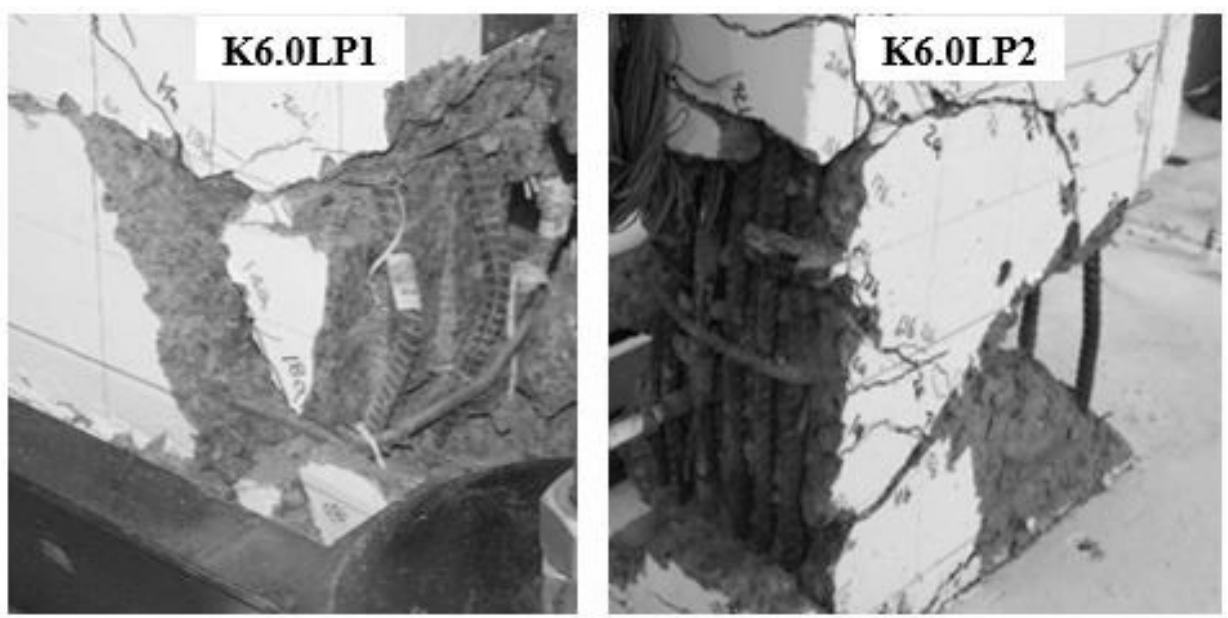

Şekil 8: Failure mode of specimens

Considering K6.0LP2 specimen which is subjected to both load and displacement controlled LP2 profile, inelastic behavior is observed for negative bending whereas for positive bending half of the plastic moment capacity is reached and unidirectional plastic hinge occurred. The plastic rotation capacity of K6.0LP2 specimen is two times of the corresponding one of K6.0LP1 specimen. Significant decrease in moment bearing capacity of test specimen occurred by buckling of 
compression reinforcement at the low reinforcement ratio side of the section. But for K6.0LP2 specimen, loading continued after buckling and test stopped due to excessive deformation despite the fact that the beam resistance was still higher than the pre-established gravity load $\left(\mathrm{F}_{\mathrm{g}}\right)$.

Load-displacement relationship of test samples are presented in Figs.10 and 11 as well as analytical displacement value obtained based on confined concrete strain for collapsing limit given in Turkish Seismic Design Code. As it is seen from Figure 10, confined concrete material strain limit given in Turkish Seismic Design Code remains insufficient to represent collapsing limit state. Although, tie spacing for both samples are approximately two third of the code requirement, experimental plastic rotation capacity is nearly two times of the one obtained by Turkish Seismic Design Code for the case of significant gravity load as it is seen in Figure 11. In other words, the main reason for the great difference -say 2.5 times- between experimental plastic rotation capacities of two identical RC beams is found to be significant gravity load effect and formation of unidirectional plastic hinge.
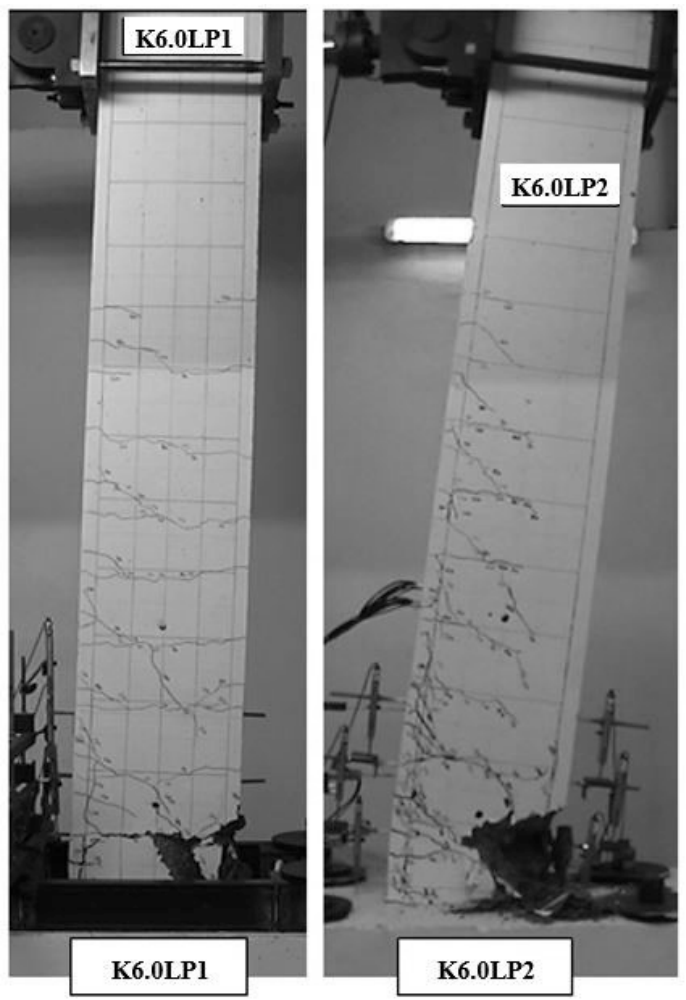

Şekil 9: Failure mode of specimens 


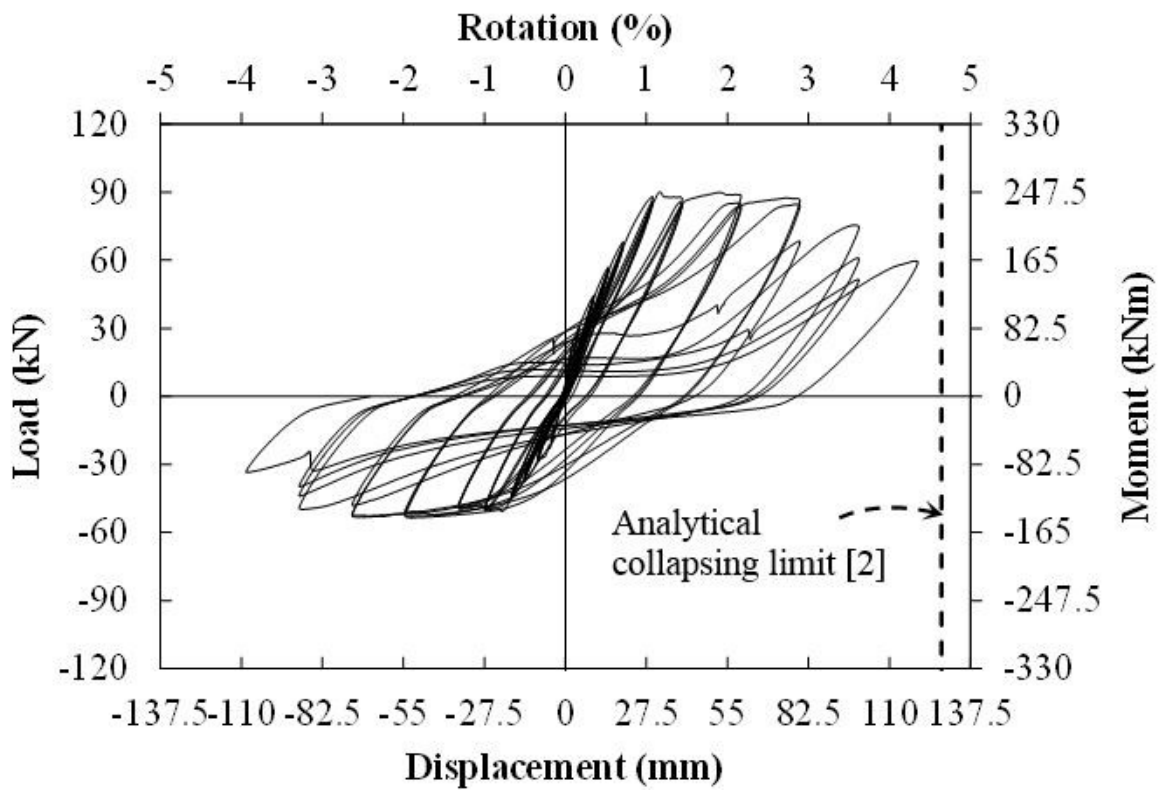

Şekil 10: Comparison of displacement capacities obtained by Turkish Seismic Design Code with experimental results (K6.0LP1)

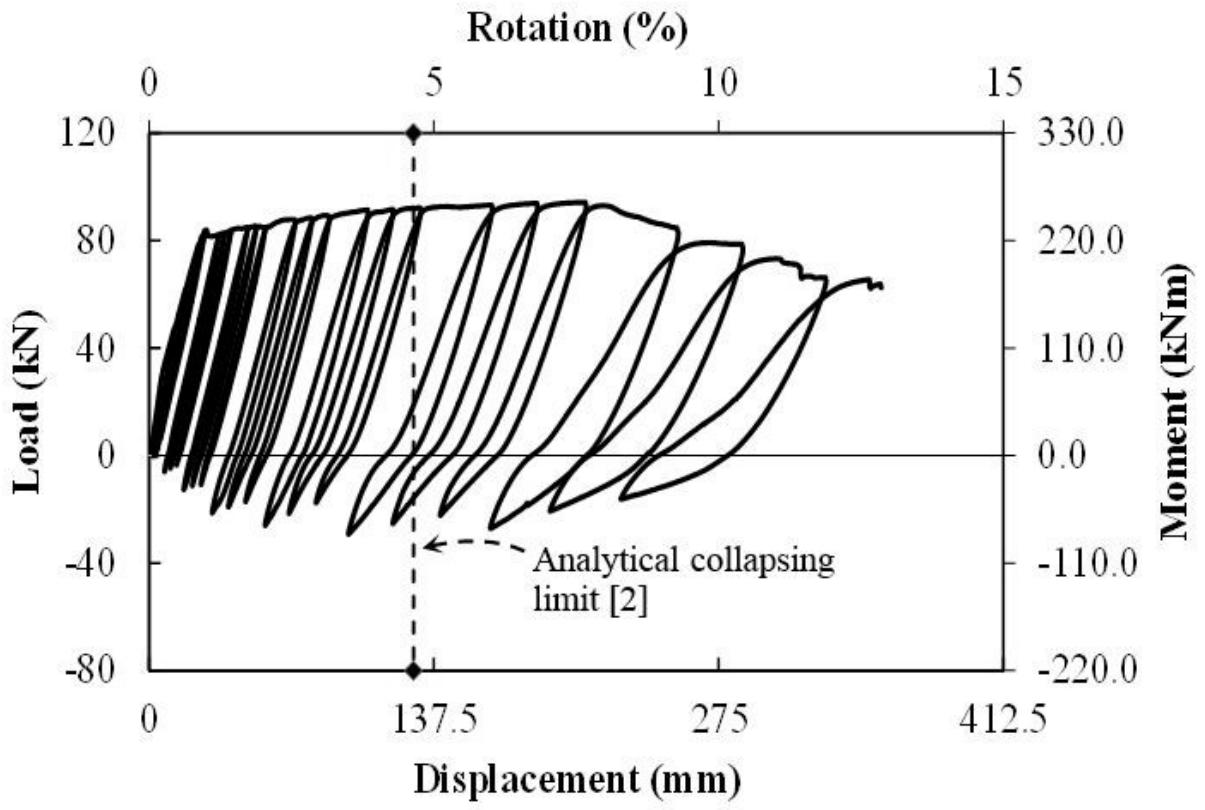

Şekil 11: Comparison of displacement capacities obtained by Turkish Seismic Design Code with experimental results (K6.0LP2) 


\section{CONCLUSION}

This study aims to investigate the seismic inelastic behavior of concrete beams with significant gravity load through experimental analyses. To this purpose, four sample beams have been produced and an experimental program is carried out in which gravity loads are applied by force controlled test procedure whereas cyclic loads are applied by displacement controlled test procedure. The results of tests with gravity load effect are compared with the results of control specimens with increasing displacement loading profile. Experimentally observed damage states and deformation demands are compared with the respective values proposed by Turkish Seismic Design Code. It is found that, the loading procedure with significant gravity load effect leads to the formation of unidirectional plastic hinges. Besides, the deformation capacities of the specimens are found to be much higher than the code based deformation capacities. The main results obtained by comparing experimental data obtained from experiments with analytical solutions are summarized below.

- The gravity load is found to be very effective on the plastic hinge forming pattern. For specimen which is subjected to displacement controlled LP1 profile that does not consider gravity load effect, reversing plastic hinges occurred for both positive and negative flexure directions.

- Considering significant gravity load effect, specimen which is subjected to both load and displacement controlled LP2 profile, inelastic behavior is observed for negative bending whereas for positive bending half of the plastic moment capacity is reached and unidirectional plastic hinge occurred.

- The plastic rotation capacity increases dramatically in case of significant gravity load effect.

- Other parameters such as plastic hinge length, displacement capacity and maximum mean strain are found to be higher in specimens with unidirectional plastic hinge formation than bi-directional plastic behavior.

Confined concrete material strain limit given in Turkish Seismic Design Code remains insufficient to represent collapsing limit state when compared to loaddisplacement relationship of test samples. Thus, the damage limit values based on the performance evaluation of existing structure should be revised.

\section{ACKNOWLEDGEMENTS}

This study is supported by Istanbul Aydin University Scientific Research Projects Center with the project number of BAP2016-01. 


\section{REFERENCES}

Turkish Seismic Design Code, Ministry of Public Works and Settlement, Ankara, 2007.

EN 1998-3, Eurocode 8: "Design of Structures for Earthquake Resistance-Part 3: Assessment and Retrofitting of Buildings", Brussels, 2003.

ECCS, "Recommended testing procedure for assessing the behaviour of structural steel elements under cyclic loads", European Convention for Constructional Steelwork, 1985.

ACI T1.1-01, "Acceptance criteria for moment frames based on structural testing”, ACI, 2001.

ATC Report No. 24, "Guidelines for seismic testing of components of steel structures”, ATC, 1992.

Corley, G. W., "Rotational Capacity of Reinforced Concrete Beams", Journal of the Structural Division, ASCE, V. 92, 121-146, 1966.

Baker, A. L. L., and Amarakone, A. M. N., "Inelastic Hyperstatic Frame Analysis", Flexural Mechanics of Reinforced Concrete, ACI, SP-12, 85-142, 1967.

Mattock, A. H., "Rotational Capacity of Hinging Regions in Reinforced Concrete Beams", Flexural Mechanics of Reinforced Concrete, ACI, SP-12, 143-181, 1967.

Eligehausen, R., and Langer, P., "Rotation Capacity of Plastic Hinges and Allowable Moment Redistribution”, CEB Bulletin, No. 175, I7.9-I7.27, 1987.

Hillerborg, A., "Fracture Mechanics Concepts Applied to Moment Capacity and Rotational Capacity of Reinforced Concrete Beams", Engineering Fracture Mechanics, V. 35, 233-240, 1990.

Bigaj, A. J., "Structural Dependence of Rotation Capacity of Plastic Hinges in RC Beams and Slabs", PhD thesis, Delft University, the Netherlands, 1999.

Bigaj, A. J., and Walraven, J., "Size Effects on Plastic Hinges of Reinforced Concrete Members”, Heron, V. 47, 53-75, 2002.

Ma, S.Y.M., Bertore, V.V, and Popov, E.P., "Experimental and Analytical Studies On Hysteretic Behavior of Reinforced Concrete Rectangular and T-Beams", Report EERC 76-2, University of California, Berkeley, May 1976, 241 pages. 
Walker A.F. and Dhakal R.P., "Assessment of material strain limits for defining plastic regions in concrete structures", Bulletin of The New Zealand Society for Earthquake Engineering, Vol. 42, No. 2, 2009.

Gião R., Lúcio V., and Chastre C., "Assessing the behaviour of RC beams subject to significant gravity loads under cyclic loads", Engineering Structures, Vol. 59, 512-21, 2014.

Megget, L. M. and Fenwick, R. C. (1989). "Seismic behaviour of a reinforced concrete portal frame sustaining gravity goads", Bulletin of NZ Society for Earthquake Engineering, Vol. 22, No. 1

ASCE, (2006). "Seismic Rehabilitation of Existing Buildings," ASCE Standard ASCE/SEI 41-06, American Society of Civil Engineers, Reston, Virginia.

Y.Jiao, S.Kishiki, S.Yamada (2012). "Loading protocols employed in evaluation of seismic behavior of steel beams in weak-beam moment frames", 201215 WCEE LISBOA 